\title{
The Price Elasticity of Electricity Demand in the United States: A Three-Dimensional Analysis
}

\author{
Paul J. Burke* and Ashani Abayasekara**
}

\begin{abstract}
In this paper we employ a dataset of three dimensions - state, sector, and year - to estimate the short- and long-run price elasticities of state-level electricity demand in the United States. Our sample covers the period 2003-2015. We contribute to the literature by employing instrumental variable estimation approaches, using the between estimator, and pursuing panel specifications that enable us to control for multiple dimensions of fixed effects. We conclude that state-level electricity demand is very price inelastic in the short run, with a same-year elasticity of -0.1 . The long-run elasticity is near -1 , larger than often believed. Among the sectors, it is industry that has the largest long-run price elasticity of demand. This appears to in part be due to electricity-intensive industrial activities clustering in low-price states.
\end{abstract}

Keywords: electricity demand, price elasticity, United States, panel

https://doi.org/10.5547/01956574.39.2.pbur

\section{INTRODUCTION}

In this study we use a three-dimensional (state*sector*year) panel dataset to estimate the short- and long-run price elasticities of state-level demand for on-grid electricity in the United States (U.S.). Our dataset consists of annual data for the residential, commercial, and industrial sectors of the lower 48 states of the U.S. over the years 2003-2015, as well as total state-level electricity use. Our estimates will be of use for projecting electricity use and for modeling the effects of tax, climate, and other policies.

There is a sizeable literature on estimating the price elasticity of electricity demand in the U.S. In terms of method, our paper contributes in several respects. First, we employ instrumental variable (IV) strategies in the identification of both short- and long-run price elasticities. Second, we estimate the long-run price elasticity using a cross-state approach that avoids the need to pursue dynamic panel techniques. Third, in estimating the short-run elasticity we utilize a three-dimensional panel approach that allows us to control for various unobserved effects, including variables common to sectors in any state (across all years), sectors in any year (across all states), and states in any year (across all sectors).

Our results suggest that the same-year price elasticity of state-level electricity demand in the U.S. is small, at around -0.1 or less for all sectors. The long-run price elasticity appears to be much larger, at around -1.0 . We find that electricity use by industry exhibits greater long-run price sensitivity than electricity use by the commercial sector, with residences a middle case. It makes

* Corresponding author. Australian National University, Australia. paul.j.burke@anu.edu.au, +61 261256566

** Institute of Policy Studies, Sri Lanka 
sense that electricity use by industry is particularly price-sensitive over the long run, as electricity-intensive production should be expected to locate in states with relatively low electricity prices (Ellison and Glaeser, 1999; Kahn and Mansur, 2013). There are also substantial input substitution and efficiency possibilities in some industrial settings.

Our study comes at a time of rapid change in electricity systems. A natural gas boom has placed downward pressure on electricity prices in some states. Technological change is reducing the cost of electricity generated using solar or wind. Efforts to reduce emissions have been introduced, and there has been growing take-up of smart meters. Time-of-day pricing is increasingly used, especially for large industrial and commercial consumers (Borenstein and Bushnell, 2015). Given these ongoing changes, it is of interest to pursue updated estimates of the price elasticity of electricity demand.

Among recent studies of the residential sector in the U.S., Alberini and Filippini (2011) used state-level data for 48 states to obtain estimates of the short-run price elasticity of electricity demand of around -0.1 and of the long-run elasticity of up to -0.7 . Miller and Alberini (2016) obtained a residential price elasticity of electricity demand of around -0.7 in their state-level panel estimate without state fixed effects for a dataset that extends to $2009 .{ }^{1}$ Using state-level panel data to 2010, Sun and Yu (2017) found short- and long-run price elasticities of residential electricity demand of -0.1 and up to -1.0 , respectively. Our results add to a consensus that the short-run price elasticity of aggregate residential electricity demand is around -0.1 and the long-run elasticity is substantially larger. Our study also explores price elasticities for other sectors.

A recent paper analyzing aggregate electricity demand for multiple sectors is that of Ros (2017). Using dynamic panel models applied to utility-level data for 1972-2009, Ros found a longrun price elasticity of electricity demand of -0.4 for residences, -0.8 for the commercial sector, and -0.6 for industry. ${ }^{2}$ Our alternative approach of using between-state variation to identify long-run effects provides larger elasticities for residences and industry, and a smaller elasticity for the commercial sector. We also explore estimates for the price elasticity of total electricity use (aggregated across all sectors). Our study uses more recent data than the study of Ros.

Labandeira et al.'s (2017) recent meta-analysis of studies from around the world reported a mean short-run price elasticity of electricity demand of -0.1 and a mean long-run elasticity of -0.4 . For U.S. states we find a similar short-run elasticity, and a larger long-run elasticity.

While our long-run price elasticity of aggregate electricity demand estimate of -1.0 is reasonably high, it is not outside the bounds of estimates of long-run price elasticities of demand for energy products. Using national-level data, Burke and Yang (2016) concluded that the long-run price elasticity of national natural gas demand is around -1.25 . Demand for road-sector gasoline is typically found to be more price inelastic; Havranek et al.'s (2012) meta-analysis concluded that the long-run price elasticity is likely to be around -0.3 .

The remainder of the paper proceeds as follows. Section 2 provides an overview of the U.S. electricity sector. Section 3 presents our methods. Section 4 describes our data. The results are presented in Section 5. Section 6 concludes.

1. Miller and Alberini (2016) also presented estimates using data at the household, utility, and city levels.

2. There are more utilities than states, so utility-level data allow a larger dataset. Ros (2017) also employed utility-level variables, including the total factor productivity of the utility. 


\section{U.S. ELECTRICITY SECTOR}

After decades of rapid growth, sales of electricity in the U.S. have plateaued since the Great Recession of 2007-2009. ${ }^{3}$ The U.S. is now the world's second-largest consumer of electricity, behind China. The U.S. Energy Information Administration (U.S. EIA, 2017)'s reference case foresees electricity use (sales plus direct use) growing at an average of less than 1\% per year to 2050 .

U.S. states have historically maintained vertically-integrated monopoly utilities with responsibilities covering generation, transmission, local distribution, and sales of electricity. These utilities have been regulated under cost-of-service arrangements. Reforms at the wholesale level since the 1990s have seen the contribution of independent power producers (IPPs) increase (Borenstein and Bushnell, 2015). As of 2015, 15 states plus the District of Columbia maintained deregulated regimes for retail electricity sales (American Public Power Association, 2016).

The U.S. net generation mix for electricity is currently dominated by coal (33\% of net generation in 2015), natural gas (33\%), and nuclear power (20\%) (U.S. EIA, 2016a). Hydro (6\%) and wind $(5 \%)$ also make important contributions. The contributions of coal and hydro have declined in recent years, and the contributions of natural gas, nuclear power, and modern renewables have increased. The electricity sector accounted for 39\% of U.S. primary energy use in 2015 (U.S. EIA, 2016b).

In 2015 the residential sector accounted for the largest share of national electricity sales, at $37 \%$. The commercial sector accounted for $36 \%$ and industry $26 \%$, down from $29 \%$ in 2004 . Transportation accounted for $0.2 \%$ of U.S. electricity sales (U.S. EIA 2016a). In this paper we focus on the three main consuming sectors, as well as total electricity sales.

Electricity prices vary across states, reflecting factors such as the availability of power plants, local fuel costs, and regulatory decisions. In 2015, the average final electricity price for the states in our sample ranged from 7.4 cents per $\mathrm{kWh}$ in Washington to 17.8 cents per $\mathrm{kWh}$ in Connecticut. Prices also vary by sector. Industry faces relatively low average prices given the large quantities consumed by industrial enterprises and their ability to receive electricity at higher voltages (U.S. EIA, 2016c).

Figure 1 shows national-average real electricity prices by sector for 2003-2015. Since 2009 , the overall average fell at a mean rate of $0.7 \%$ per annum in real terms. The fastest reduction has been for industry (at an average rate of $1.5 \%$ per annum). National averages mask substantial differences in the electricity price trends of individual states. Over 2009-2015, the mean real electricity price fell at an average rate of $3.7 \%$ per annum in Texas (the state with the fastest decline), while it increased by $3.1 \%$ per annum in North Dakota (the state with the fastest increase).

Figure 2 presents the relationship between the log average electricity price and log electricity sales per capita for the 48 states in 2015. As should be expected, a strong negative association can be seen. The fitted line has an $R^{2}$ of 0.66 . Per capita electricity sales tend to be highest in relatively low-price states such as Wyoming, North Dakota, Louisiana, and Alabama. Per capita electricity sales are lowest in high-price states such as California, Rhode Island, New York, and Massachusetts.

3. Electricity sales grew at an average rate of $7 \%$ per annum in the $1960 \mathrm{~s}, 4 \%$ in the $1970 \mathrm{~s}, 3 \%$ in the $1980 \mathrm{~s}, 2 \%$ in the 1990 s, and $1 \%$ in the first decade of the new millennium. Electricity sales in 2015 were slightly below those in 2007 . This was due to reduced sales to industry and to the transportation sector. Sales to residences and the commercial sector were slightly higher in 2015 than in 2007 (US EIA, 2016a). 
Figure 1: Average Real Electricity Price by Sector, 2003-2015

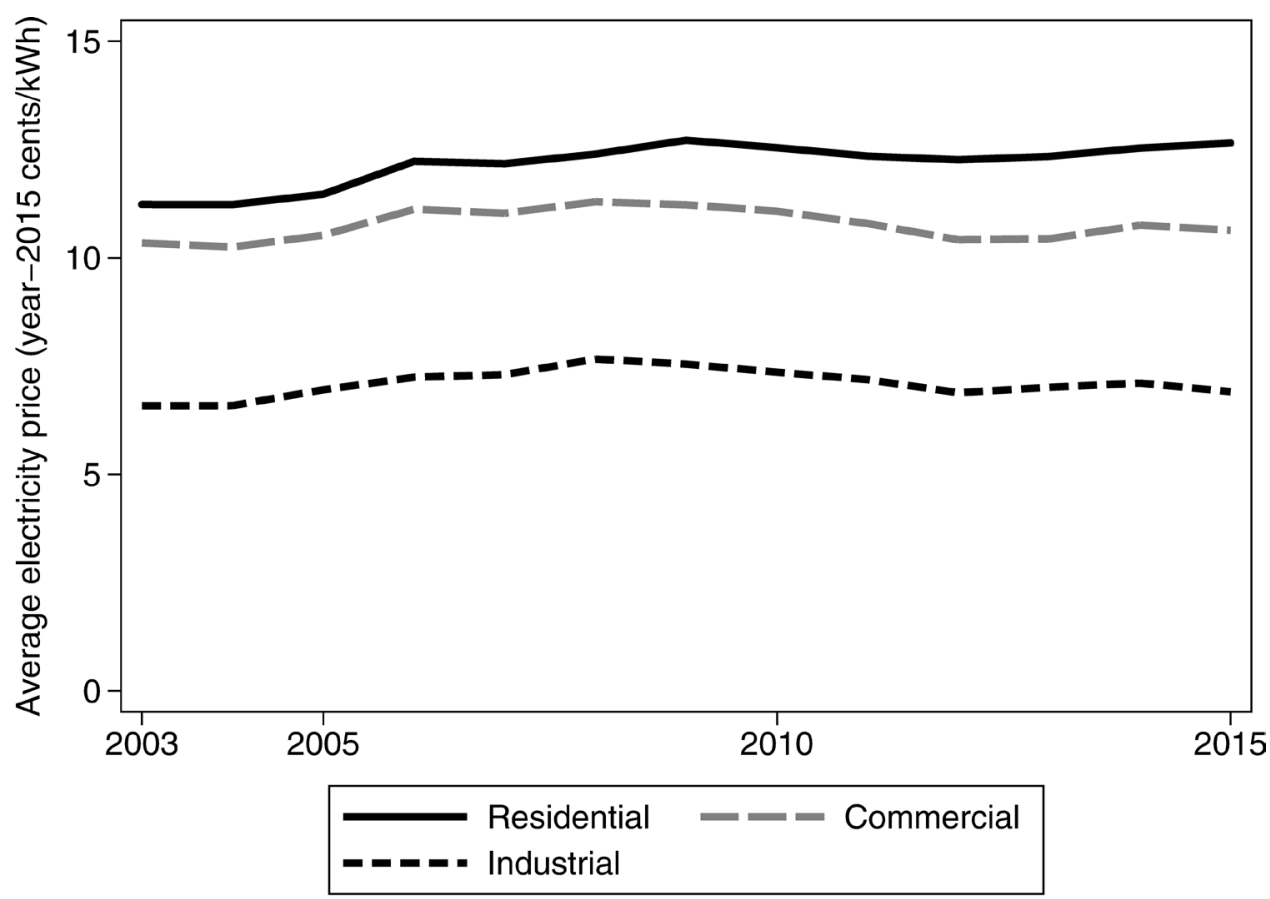

Note: Generated using national-total data from the U.S. EIA (2016a), deflated using the national consumer price index (urban consumers) from the Bureau of Labor Statistics (2017). Data do not cover direct use of self-generated electricity.

\section{METHODS}

We commence with a cross-state method for obtaining long-run elasticities and then describe our panel approach in first differences for obtaining short-run elasticities.

\subsection{Method for long-run elasticity}

Prior studies typically seek to identify the long-run price elasticity of electricity demand via dynamic models with lagged dependent variables (e.g. Houthakker, 1980; Dergiades and Tsoulfidis, 2008; Alberini and Filippini, 2011; Ros, 2017; Sun and Yu, 2017). These studies back-out an implied long-run multiplier based on forward simulations of their model, using a formula that divides the short-run multiplier by $1-\psi$, where $\psi$ is the coefficient on the lagged dependent variable.

We avoid the above approach, for several reasons. Dynamic models require an assumption about the exact form of the dynamic process, a challenging task when the effects of price shocks may be realized with varying lag lengths. Panel estimates that use lagged dependent variables are affected by the issue of dynamic panel bias (Nickell, 1981; Barro, 2015). Methods for addressing this issue, such as differenced and system generalized methods of moments (GMM) techniques, can be unreliable when data are non-stationary (Blundell and Bond, 1998; Roodman, 2009), as is the case for U.S. electricity sales (see discussion below). These methods are also sensitive to specification choices, measurement error, and weak instruments (Hauk and Wacziarg, 2009; Bun and Windmeijer, 2010; Bazzi and Clemens, 2013; Hauk, 2017). 
Figure 2: Log Average Electricity Price and Log Per Capita Electricity Sales Across States in the U.S., 2015

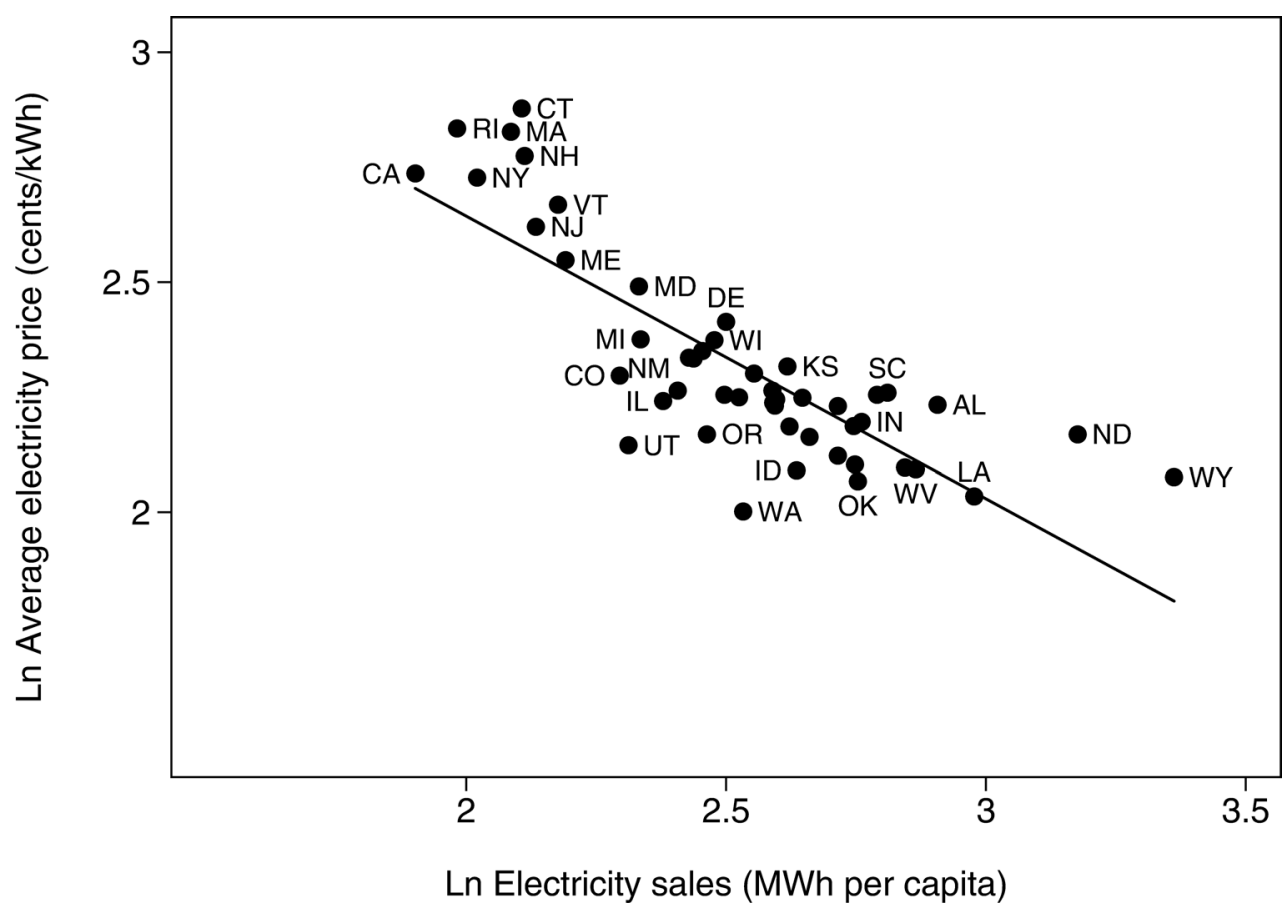

Note: 48 states included, as per our regressions. The fitted line has an $R^{2}$ of 0.66 . Generated using data from the U.S. EIA (2016a). Price is shown on the $y$ axis in accordance with the standard presentation of a demand curve. The average electricity price for consumption across all sectors is used. Electricity sales have been converted to per capita terms to remove the effect of population. In our regressions, this is done by controlling for Ln Population.

We instead pursue a simpler way forward: we isolate long-run effects by exploiting the "between" variation in electricity prices and electricity use across states. This is the variation that is observable in Figure 2. We exploit the between variation using both cross-sectional regressions and, in the panel context, the "between estimator". The between estimator utilizes the means of each variable for each state over the full time period, providing long-run effects without requiring any specification of dynamics (Baltagi and Griffin, 1984; Pesaran and Smith, 1995; Pirotte, 1999, 2003; Baltagi, 2008). The approach avoids issues related to non-stationarity of time-series data, and there is evidence that it is subject to less bias than panel methods that focus on the "within" variation in the data (Hauk and Wacziarg, 2009; Hauk, 2017). Stern (2010, p. 2175) concluded that the between estimator is the "best estimator of long-run relations in panel data". The approach has been increasingly used to estimate long-run effects in applied economics research (e.g. Burke and Nishitateno, 2013, 2015; Delgado et al. 2014; Edwards, 2016; Ma and Stern, 2016), although has yet to be used to estimate the long-run price elasticity of electricity demand in the U.S. A key concern with the between estimator is that it can be subject to omitted variable bias. We use an IV strategy to address this issue.

We commence with cross-state regressions for the year 2015. Assuming each state is in a long-run equilibrium, these provide information on the long-run reasons for variation in electricity sales across states. We estimate the following model: 


$$
\ln E_{s}=\alpha+\beta \ln P_{s}+\gamma \ln Y_{s}+\delta \ln N_{s}+\boldsymbol{X}_{s}^{\prime} \boldsymbol{\theta}+\varepsilon_{s}
$$

where $E$ is electricity sales in state $s$, in gigawatt-hours (GWh) per year; $P$ is the average real final price of electricity in cents per kilowatt hour; $Y$ is GDP per capita per year, in real dollars; $N$ is population; $\boldsymbol{X}$ is a vector of other potential determinants of electricity demand; $\varepsilon$ an error; and ln denotes the natural logarithm. We estimate Eq. (1) for three sectors: residences, the commercial sector, and industry. We also present an estimate for total electricity sales in each state. These regressions each use one dimension of the dataset (the cross-state dimension).

After presenting cross-state estimates for 2015 we compare these to estimates for 2003, the first year of our sample. We then proceed to estimates using the between estimator for the full period 2003-2015. Our interest is $\hat{\beta}$, an estimate of the long-run price elasticity of electricity demand.

Our use of a log-log specification follows the standard approach in prior studies (e.g. Shin, 1985; Miller and Alberini, 2016; Ros, 2017; Sun and Yu, 2017). A log-log specification has some attractive properties, including (a) directly providing elasticities, (b) producing residuals with more desirable distributions, ${ }^{4}$ (c) ensuring that the predicted values of electricity consumption are always positive, and (d) reducing the potential influence of outliers. Strong negative associations between price and quantity are obtained in specifications using unlogged variables. We also tested the inclusion of a squared log price term in the cross-sectional regression for total electricity sales in 2015, but it entered insignificantly.

Estimating Eq. (1) is subject to an identification challenge: because average electricity prices are calculated as total revenue from electricity sales divided by the total quantity of sales in $\mathrm{kWh}$, our key explanatory variable is affected by the dependent variable. The existence of block pricing arrangements, for example, means that higher electricity demand may directly influence the average electricity prices paid by customers. Another issue is that high demand might push states toward more expensive electricity sources, forcing up the state's average electricity price. Unobserved factors may also be correlated with both electricity demand and electricity use. While retail electricity prices remain regulated in many states, this does not make them exogenous to electricity demand.

We adopt an IV approach to address this potential endogeneity of our electricity price measure. An ideal instrument would be a supply-side factor that affects average electricity prices but is not directly correlated with demand for electricity. We use the coal plus hydro share of the net electricity generation mix. When only private costs are considered, coal and hydro have been among the lowest-cost sources of electricity generation in the U.S. ${ }^{5}$ The coal plus hydro share of the electricity mix is thus likely to be negatively correlated with average electricity prices.

One issue with the above IV approach is that high demand might lead to a change in energy mix, for example by pushing states to adopt energy sources other than coal and hydro. This would affect our instrument. To reduce this possibility we use the ten-year lag of the coal plus hydro share. ${ }^{6}$ Our identification strategy thus exploits the fact that coal and hydro have historically been relatively low-cost electricity sources and the expectation that - whether due to ongoing use of coal plus hydro or to some stickiness in state-by-state rankings in electricity prices - states that have historically had high coal plus hydro shares of the net generation mix currently have relatively low average electric-

4. We plotted the residuals against the fitted values for the 2015 cross-sectional regressions by sector. Systematic patterns in the residuals were more likely to be observable for the unlogged regressions.

5. This is less the case now than it was in earlier years as a result of reductions in the costs of natural gas and modern renewables.

6. We obtain similar results using the 25-year lag. 
Figure 3: Ln Average Electricity Price (2015) and the Coal Plus Hydroelectricity Share of Electricity (2005)

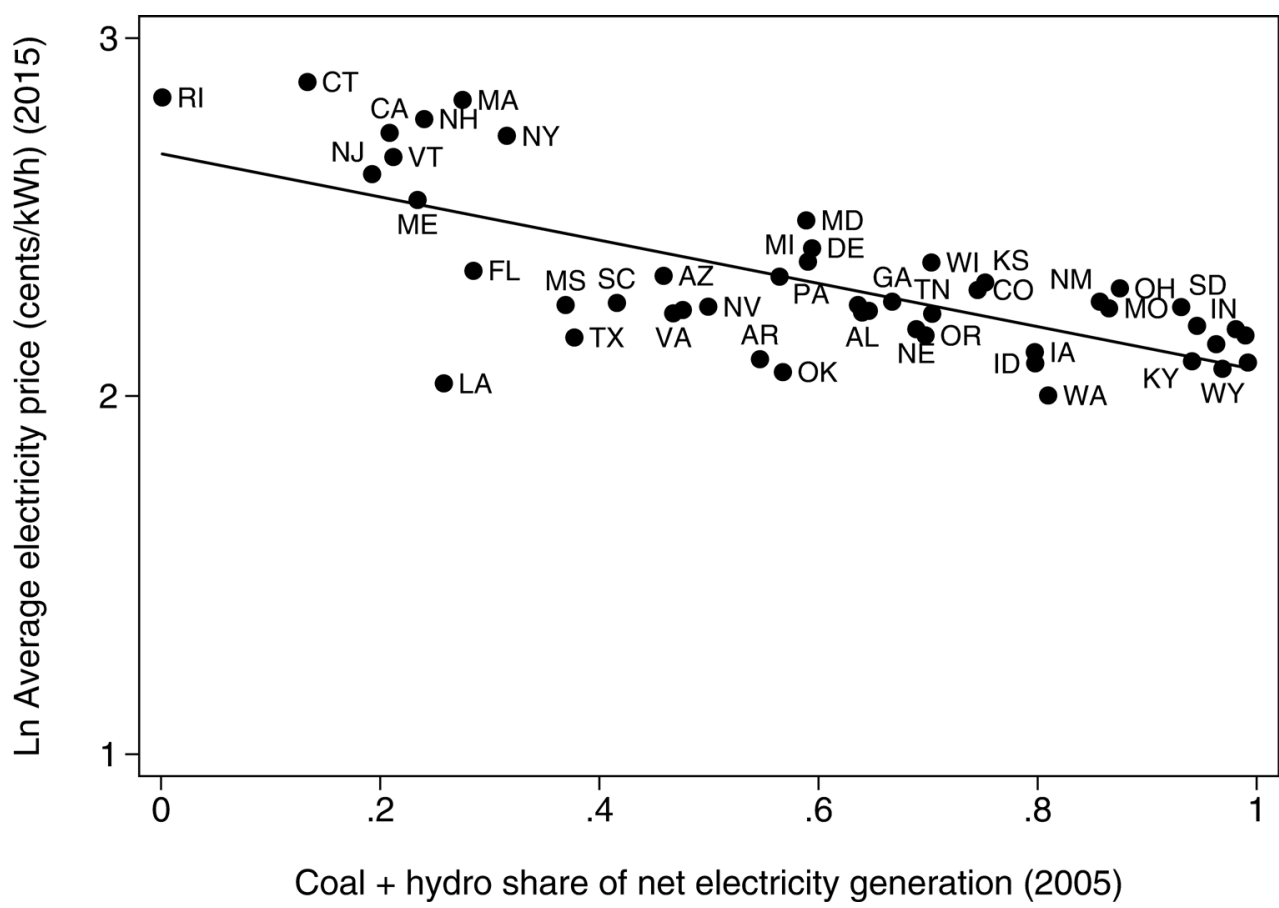

Note: 48 states included. The average electricity price is for consumption across all sectors. The fitted line has a slope of -0.60 and an $R^{2}$ of 0.51 . Uses data from U.S. EIA (2016a). Hydro excludes pumped storage. The share ranges from 0 to 1 . Codes are not shown for all states.

ity prices. ${ }^{7}$ The approach shares some similarities with that of Fell et al. (2014), who instrumented with fuel mix shares and fuel mix shares interacted with fuel prices.

A negative association between the ten-year lagged coal plus hydro share of the electricity mix and the state-average electricity price is demonstrated in Figure 3. The fitted line has a coefficient of -0.60 , indicating that an additional 10 percentage points of the net generation mix from coal plus hydro in 2005 is on average associated with around a $6 \%$ lower average electricity price as of 2015. States that had low reliance on coal plus hydro in 2005 - such as Rhode Island, Connecticut, and New Jersey - tended to face relatively high final electricity prices. States that have relied on coal plus hydro for nearly all of their electricity—such as West Virginia, North Dakota, and Montana-tend to have lower prices.

A requirement for our IV approach is that the coal plus hydro share of the electricity mix is only relevant for electricity sales via the electricity price. It is possible that consumers curtail their electricity use when they know electricity in their state is generated by (emissions-intensive) coal, but any such effect is likely to be minor. Abundance of coal and water might be directly linked to industrial activity, and hence electricity use. For this reason, the IV exclusion restriction may be more credible for residences than industry. We nevertheless believe our IV strategy worth pursuing given

7. In deregulated wholesale markets, the wholesale price is set by the marginal electricity source. During times of peak usage, this is often natural gas. At other times, other generation sources can influence the wholesale price. The coal plus hydro share of electricity generation can thus influence average annual wholesale prices, and in turn average annual retail prices. Borenstein and Bushnell (2015) note that hydro availability influences wholesale prices in the Pacific Northwest. 
the strength of the direct channel between the instrument and electricity prices. We will present both single-equation and IV results.

Our $\boldsymbol{X}$ vector includes the following controls: the log number of heating degree days (HDD) in each state, as some heating systems use electricity; the log number of cooling degree days (CDDs), as air conditioning is a major source of electricity demand, especially for residences; ${ }^{8}$ the log real citygate natural gas price; and a logged time-invariant measure of the extent to which each state's congressional delegations voted in a pro-environment way over the full period 1990-2005, from Dietz et al. (2015). We include the latter because pro-environment states might introduce measures that increase retail electricity prices (e.g. an emissions trading scheme) in addition to separate measures to directly improve energy efficiency, creating a potential omitted variable issue in the absence of the control. We include the log real natural gas price because natural gas is a key potential substitute for electricity (in addition to being an input to electricity generation). Results are similar without this control. We avoid controlling for the industrial structure of each state's economy, as this might be affected by electricity prices; including such a control would potentially attenuate our estimates. We include the same set of controls for each sector.

\subsection{Method for short-run elasticity}

To estimate the short-run price elasticity of electricity demand for U.S. states, we commence with the following two-dimensional panel specification by state $(s)$ and year $(y)$, using data for total electricity use across all sectors:

$$
\Delta \ln E_{s, y}=\alpha+\beta \Delta \ln P_{s, y}+\gamma \Delta \ln Y_{s, y}+\delta \Delta \ln N_{s, y}+\Delta \boldsymbol{X}_{s, y}^{\prime} \boldsymbol{\theta}+\eta_{s}+\eta_{y}+u_{s, y}
$$

$\hat{\beta}$ is here intended to be the short-run - i.e. same-year - price elasticity of state-level electricity demand. ${ }^{9}$ Eq. (2) controls for state $\left(\eta_{s}\right)$ and year $\left(\eta_{y}\right)$ fixed effects. ${ }^{10}$ The state fixed effects control for state-specific differences in electricity use growth. The year fixed effects control for time-specific shocks that could impact electricity use. $\Delta$ is the first-difference operator, and $u$ an error. The $\boldsymbol{X}$ vector is the same as earlier, other than that it excludes the environmental voting measure as this is time-invariant and so disappears in the differencing.

Eq. (2) uses first differences for two reasons. One is that taking first-differences hones in on the effect of year-to-year shocks, suiting a short-run interpretation. Second, Dickey and Fuller (1979) tests with linear time trends on aggregate data for the U.S. were unable to reject the nulls that the logs of national electricity sales and the national-average real electricity price contain unit roots. This means that shocks may have permanent effects on the levels of the variables. The nulls of unit roots were rejected for the first-differences. Using data in first differences allows us to avoid potential spurious regression results arising from unit root issues.

We finally move to the following three-dimensional specification, using a panel of states $(s)$, sectors $(g)$, and years $(y)$ :

8. Our use of degree day controls in logged form follows the standard approach in the literature. See, for example, Ros (2017).

9. It is possible to use alternative data to analyze responses over shorter timeframes, for example by 15 -minute period (e.g. Jessoe and Rapson, 2014).

10. Random effects provide similar results. We do not include a common time trend, which would be perfectly collinear with the year fixed effects. 


$$
\Delta \ln E_{s, g, y}=\alpha+\beta \Delta \ln P_{s, g, y}+\gamma \Delta \ln Y_{s, y}+\delta \Delta \ln N_{s, y}+\Delta \boldsymbol{X}_{s, y}^{\prime} \boldsymbol{\theta}+\eta_{s, g}+\eta_{g, y}+\eta_{s, y}+u_{s, g, y}
$$

Eq. (3) includes three sets of two-dimensional fixed effects:

(a) state* sector fixed effects $\left(\eta_{s, g}\right)$, to control for unobserved differences in electricity sales growth rates in each sector in each state;

(b) sector*year fixed effects $\left(\eta_{g, y}\right)$, to control for unobserved differences in electricity sales growth rates in each sector in each year; and

(c) state*year fixed effects $\left(\eta_{s, y}\right)$, to control for unobserved differences in electricity sales growth rates in each state in each year. To avoid perfect collinearity, we exclude the observed controls when these fixed effects are included.

Using the three-dimensional panel structure, we explore if the short-run price elasticity of electricity demand varies by sector, over time, by region of the U.S., and for real price increases and decreases.

A potential endogeneity issue exists for our short-run estimates: same-year changes in electricity prices may be affected by same-year changes in electricity demand, or be correlated with omitted variables. To address this issue, we also pursue an IV approach in our three-dimensional panel estimates: we instrument the change in the log average electricity price per $\mathrm{kWh}$ in sector $j$ using the change in the log average electricity price paid by all consumers outside the sector but in the same state and year. ${ }^{11}$ The average price paid by these other consumers is not directly influenced by feedback from quantity demanded within a sector. Given that proportional changes in electricity tariffs in any state and year are often similar for each sector, the approach thus seeks to exploit a somewhat more exogenous source of variation in electricity prices. We exclude the state*year fixed effects when pursuing this IV strategy. We do not instrument our two-dimensional estimates.

\subsection{Additional issues}

Breusch and Pagan (1979) tests reject the null of no heteroscedasticity, both for the crossstate and panel models. Wherever possible, we present standard errors that are robust to heteroscedasticity. ${ }^{12}$ Wooldridge (2002) autocorrelation tests suggest the possible presence of first-order autocorrelation in our differenced panel settings. In our two-dimensional panel we thus also cluster the standard errors at the state level to take state-specific patterns of autocorrelation into account. In our three-dimensional panel, standard errors are clustered by state*sector.

States are heterogeneous in terms of their electricity sales. In 2015, electricity sales in Texas equaled $392 \mathrm{TWh}, 10 \%$ of the national total. There was only $5 \mathrm{TWh}$ of electricity sold in Vermont, $0.1 \%$ of the national total. Given this heterogeneity, our estimates use weighted least squares (WLS), with a weight equal to the square root of the number of consumers for each panel observation. ${ }^{13}$

Our use of final consumer prices and electricity consumption by final consumers is suited to the estimation of a demand (cf. supply) function. It is possible that log GDP per capita is co-determined with electricity demand, but we find similar estimates in specifications that exclude this

11. This is consumers in the other two sectors plus the transportation sector.

12. Robust standard errors are not available for the between estimator.

13. For the residential and commercial sectors, this weight is highly correlated with population (correlation coefficients $=0.94)$. For industry, this correlation is lower $(0.66)$. 
variable. The state*year fixed effects will control for interruptions to electricity availability in any state in any year. Our analysis assumes that electricity is otherwise available at prevailing prices.

We expect $\hat{\beta}$ to be negative, consistent with a downward-sloping demand curve. This elasticity is likely to be larger in the long run than the short run, as learning about and responding to price changes likely takes time. As mentioned, there are reasons to think that the long-run elasticity will be particularly large for industry if electricity-intensive processes tend to locate in states with low electricity prices.

\section{DATA}

Our dataset has three dimensions: state, sector, and year. The states are the 48 contiguous U.S. states. ${ }^{14}$ The sectors are residential, commercial, and industrial consumers. The years are 2003-2015. The sample starts in 2003 because this is the first year for which the current U.S. EIA (2016a) sectoral definitions were used. Our between panel estimates thus cover 624 observations (48 states*13 years) for each sector. One year is lost in the first-differencing, meaning that our three-dimensional estimates cover 1,728 observations (48 states*3 sectors*12 years). Our two-dimensional estimates cover 576 observations (48 states*12 years). All panels are balanced.

Our electricity price measure is the real price paid by end-use consumers, averaged across all $\mathrm{kWh}$ in year-2015 cents per $\mathrm{kWh}$. It is calculated by dividing revenue from electricity sales by the quantity of electricity sold. Revenue includes all relevant end-user charges, fees, and taxes. We deflate using the regional consumer price index from the Bureau of Labor Statistics (2017). ${ }^{15}$ Our use of an average price receives support from evidence that information and cognitive constraints cause households to respond to the average rather than the marginal electricity price (Shin, 1985; Ito, 2014), although this may be less applicable for commercial and industrial consumers. Our dependent variable uses data on electricity sales, which excludes captive generation ("direct use") of electricity.

Our main sources of data are the U.S. EIA (2016a, 2016e), the Bureau of Economic Analysis (BEA, 2017), National Oceanic and Atmospheric Administration (NOAA, 2016), and Dietz et al. (2015). Variable definitions and data sources are listed in the Appendix. Summary statistics are in Table 1. The statistics show that there is substantial variation in all variables. Average real electricity prices on average increase at a rate of around $1 \%$ per annum, but with a standard deviation that is several times this magnitude. Variability in the growth rate of average electricity prices is particularly pronounced for the industry sector.

\section{RESULTS}

\subsection{Long-run estimates}

Table 2 presents our cross-state estimates for 2015. Estimates for residences are presented first (columns 1-2), followed by estimates for the commercial sector (columns 3-4), industry (columns 5-6), and then total electricity sales in each state (columns 7-8).

Focusing firstly on the residential estimates, the long-run price elasticity of electricity demand is estimated to be -0.95 in the single-equation estimate and -1.01 in the IV estimate. The similarity of these estimates suggests that endogeneity issues are not substantial at the residential

14. Alaska and Hawaii are excluded due to missing data for some controls (see Appendix).

15. Results using nominal prices are similar. A breakdown into fixed and variable charges is not available. 


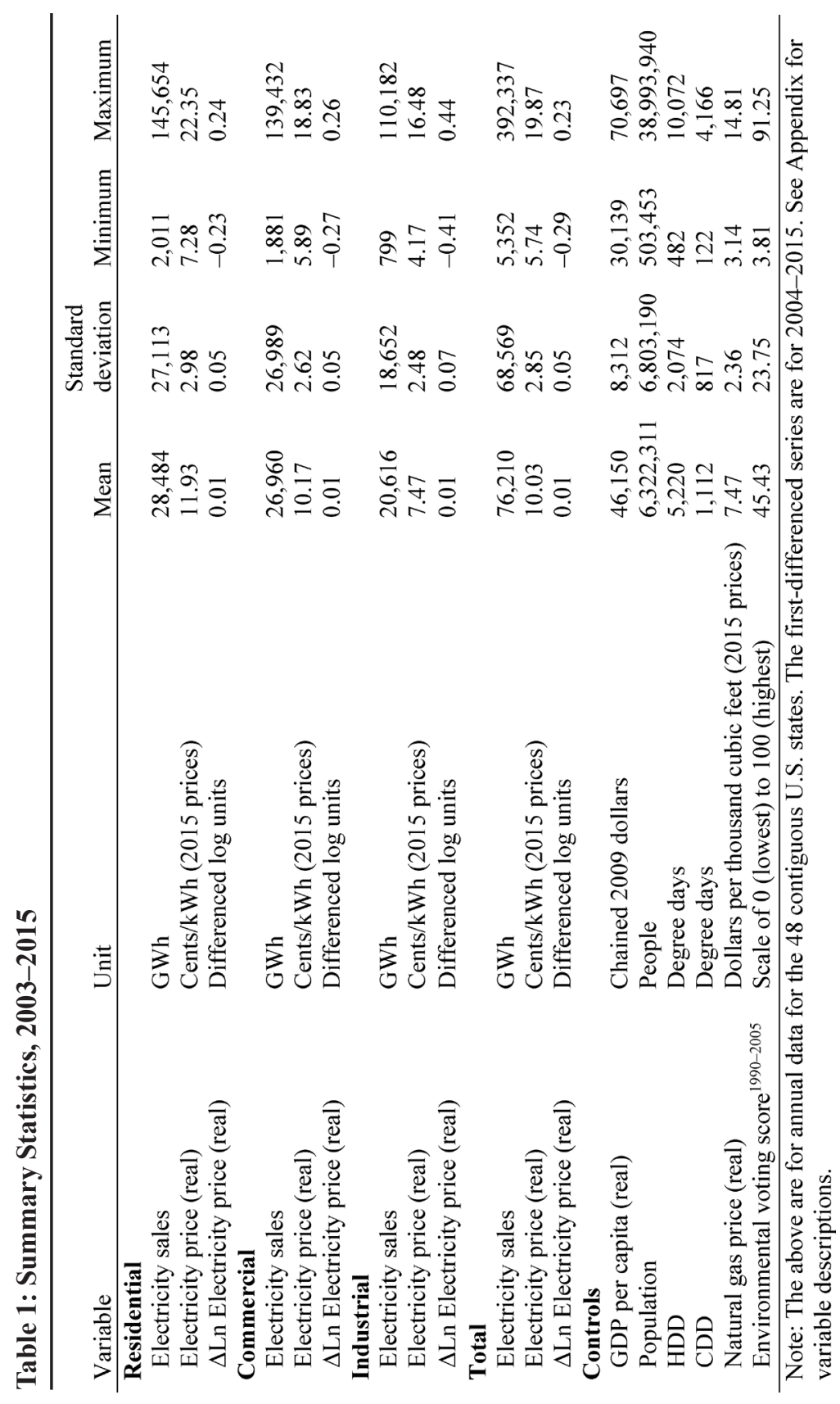




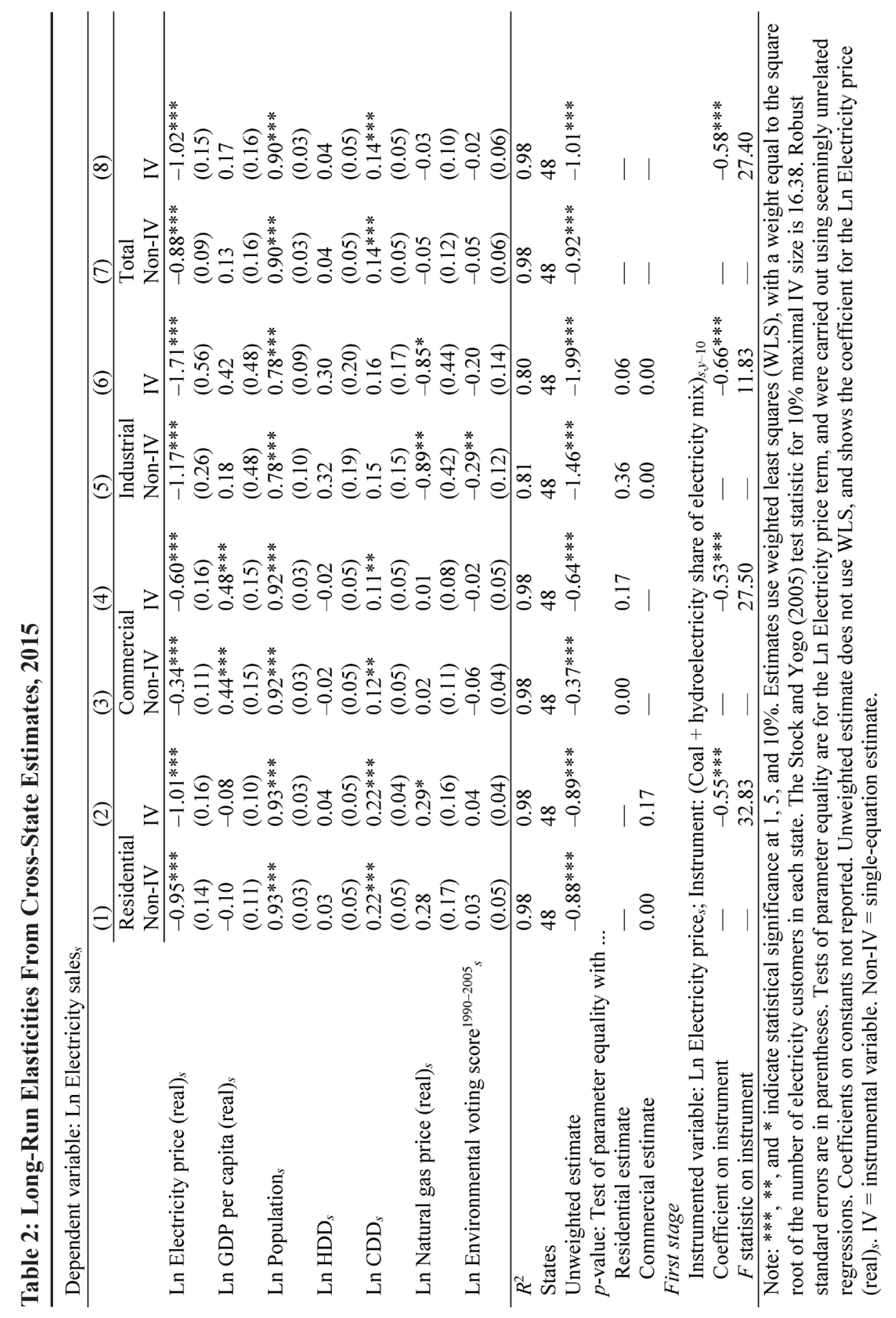


level. ${ }^{16}$ The coefficient for population is 0.93 , suggesting that more populous states consume more electricity for residential purposes, as expected. Having more cooling degree days is associated with greater electricity use by residences, presumably mostly in the form of air-conditioner use. The other variables do not have robustly significant influences on residential electricity use.

Turning to the commercial sector, we obtain estimates of the long-run price elasticity of electricity demand of -0.34 (single-equation) and -0.60 (IV). The single-equation estimate is significantly smaller than that for residences. A positive coefficient is obtained for log GDP per capita, suggesting that states with higher per-capita GDP use more electricity in commercial activities. Population and CDD have positive effects on commercial electricity use.

The estimates in columns 5-6 of Table 2 suggest that state-level electricity sales to industry are particularly sensitive to electricity prices. We obtain long-run price elasticities of on-grid electricity demand by industry of -1.17 (single-equation) and -1.71 (IV), both significantly larger than the estimates for the commercial sector. A state's population is somewhat less relevant for industrial electricity use, with a population-electricity use elasticity of 0.78 . We also find evidence that natural gas and electricity are complements for industry. This makes sense, as these energy forms are often joint inputs.

Our estimates for total electricity sales (columns 7-8 of Table 2 ) indicate that long-run aggregate electricity demand is quite close to having unitary price elasticity. The point estimate for the long-run population elasticity is 0.90 , and for the CDD elasticity is 0.14 . Log GDP per capita enters positively but insignificantly. The variables in our model are able to explain $98 \%$ of the variation in log electricity sales across U.S. states. Almost all of this explanatory power is from two variables: $\log$ population and the log average electricity price.

The base of Table 2 provides information on the first stage of our IV estimates. Strong identification is obtained for residences, the commercial sector, and in total, with first-stage $F$ statistics on our instrument of up to 32.83. These pass the Stock and Yogo (2005) test for weak instruments. First-stage identification is weaker for industry. The base of Table 2 also shows that the unweighted estimates are generally quite similar to the WLS estimates.

Figure 4 compares point estimates for 2015 with those from the first year of our sample, 2003. The largest difference in point estimates is for the IV specifications for industry. In all cases, however, the estimate for 2003 is not significantly different from the corresponding estimate for 2015.

Table 3 presents long-run elasticities using the between estimator for the period 20032015. ${ }^{17}$ The price elasticities are in general quite similar to the cross-sectional estimates for 2015, again indicative of relatively stable relationships. The point estimates for industry remain quite large. On the basis of Tables 2 and 3 we conclude that the long-run price elasticity of electricity demand is around -1 for residences, between -0.3 and -0.6 for the commercial sector, -1.2 or larger for industry, and around -1 in total.

A positive and significant effect of GDP per capita on total electricity sales is detected in the between estimates in Table 3: $1 \%$ higher GDP per capita is typically associated with $0.4 \%$ more electricity sales (ceteris paribus). This is largely due to additional electricity sales to the commercial sector. The coefficients for $\log$ HDD and $\log$ CDD are insignificant, with the key exception being the

16. Recent studies of the long-run price elasticities of demand for gasoline (Burke and Nishitateno, 2013) and natural gas (Burke and Yang, 2016) also find quite similar single-equation and IV results.

17. Analytic weights are not available for the between estimator in Stata. Table 3 consequently does not use weights. 
Figure 4: Long-Run Price Elasticities of Electricity Demand From Cross-State Estimates, 2003 and 2015

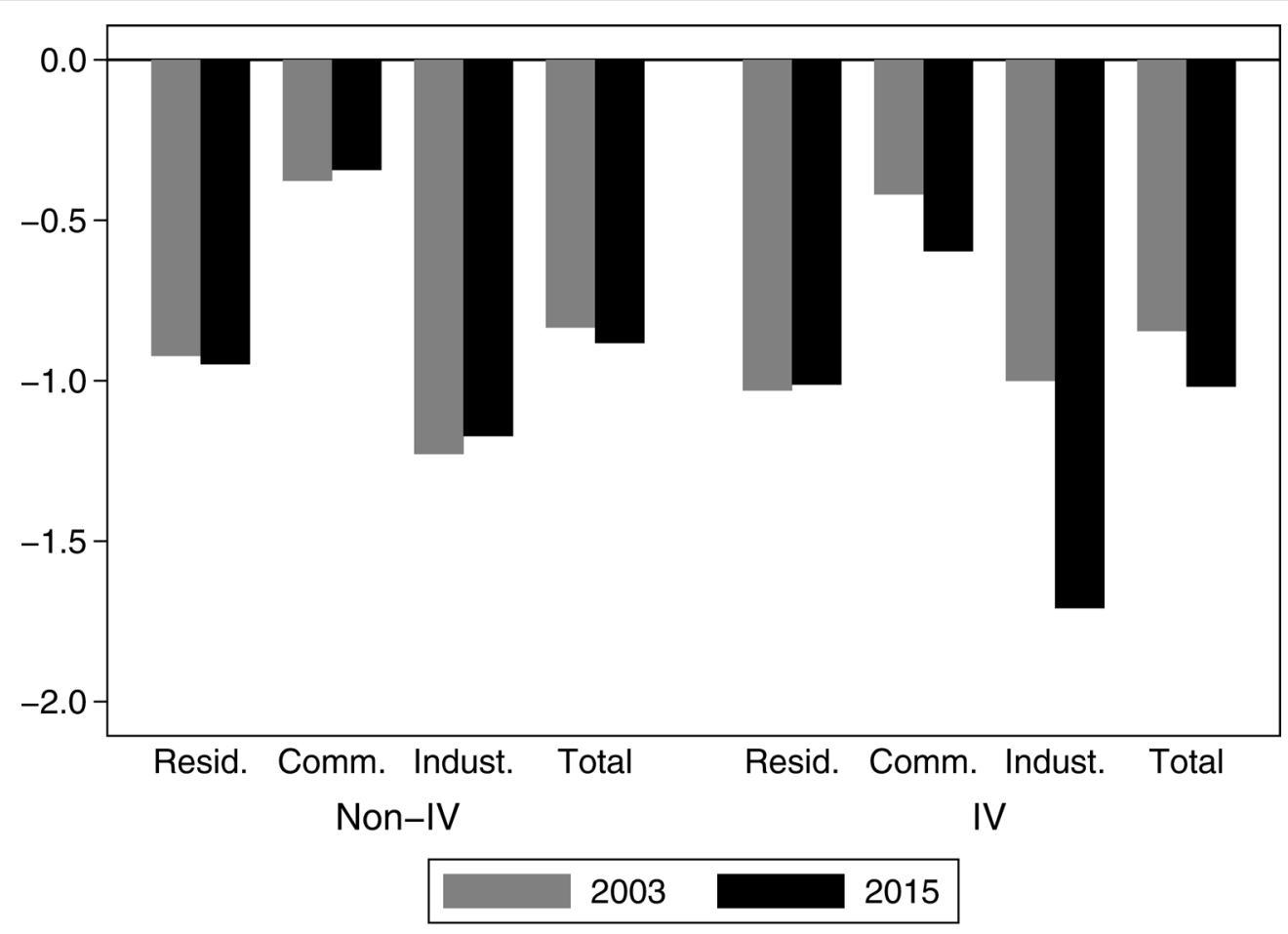

Note: 2015 estimates are the same as those in Table 2. 2003 estimates use the same estimation strategy. Resid. = residential. Comm. $=$ commercial. Indust. $=$ industrial. The $p$-values for tests of parameter equality for 2003 and 2015 for each of the eight sets of estimates are: $0.88,0.80,0.86,0.66,0.95,0.41,0.29$, and 0.49 . The 2003 and 2015 estimates are thus not significantly different from one another. These tests were carried out using seemingly unrelated regression estimates.

negative coefficients obtained for log HDD for residences. ${ }^{18}$ The natural gas cross-price elasticities differ from those in Table 2, with stronger evidence being obtained that natural gas is a substitute for electricity at the residential level.

As discussed, part of the reason for a large long-run price elasticity of electricity demand for industry could be that electricity-intensive industrial activities tend to concentrate in states with low electricity prices. Take the aluminum industry as an example. As of 2015, Washington (23\%) and Kentucky (23\%) made the largest contributions to U.S. primary aluminum production capacity (U.S. Geological Survey, 2016). Washington had the lowest average electricity price for industry of all U.S. states in 2015, and Kentucky the fifth-lowest. Unreported cross-state regressions for 2015 reveal a negative association between the average industrial electricity price of each state and its aluminum production capacity (including when we use our instrument). Kahn and Mansur (2013) provide detailed evidence that energy-intensive industry concentrates in locations with low electricity prices.

18. The negative coefficient for log HDD for residences is perhaps because residences in cold states tend to use natural gas for heating. If connected to natural gas, residences would tend to use this fuel for other purposes also, such as cooking. Hence their electricity use might be lower. Estimates of the long-run price elasticity of electricity demand remain generally similar without the degree day controls. 


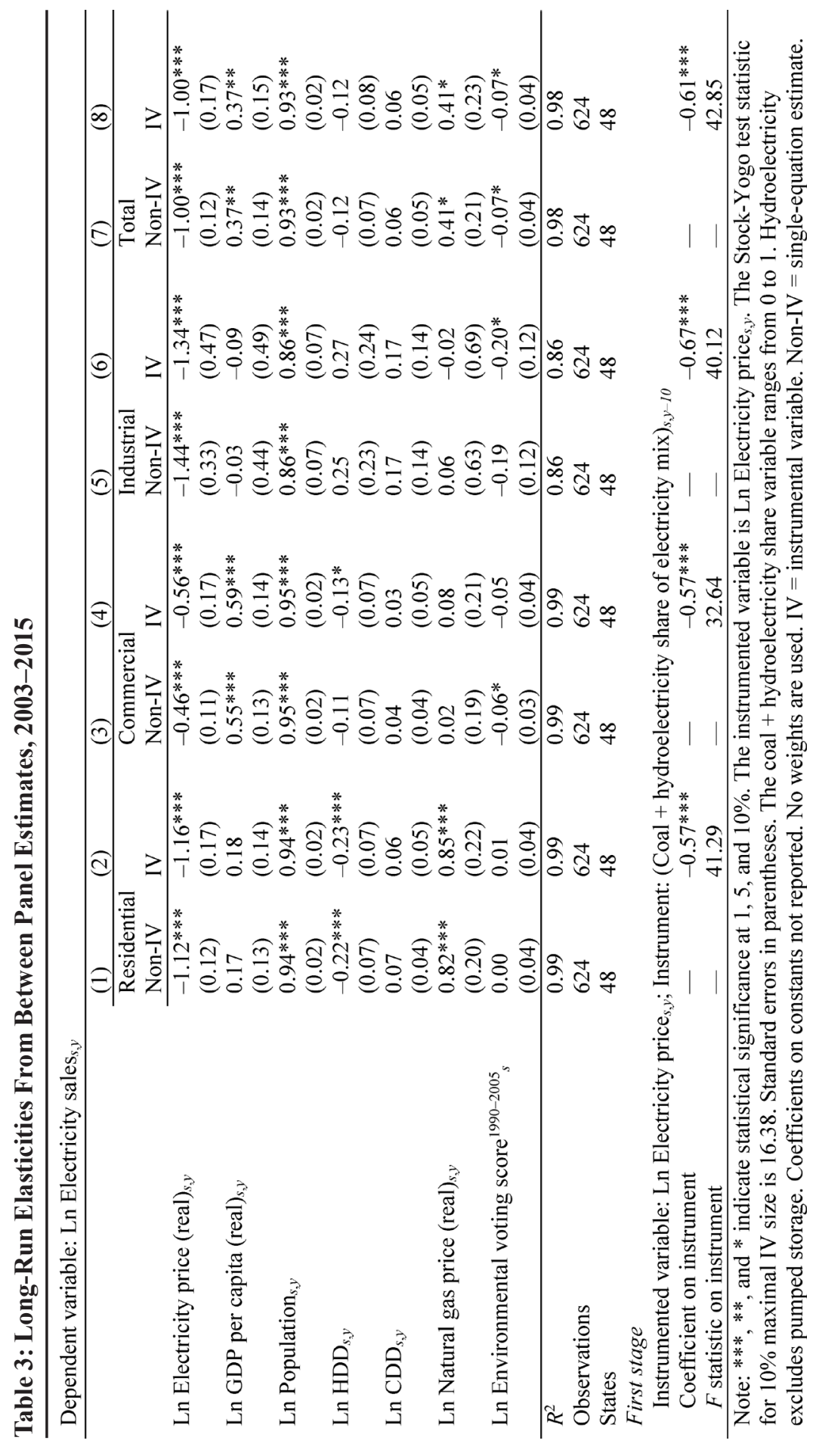


Table 4: Two-Dimensional Estimates in First-Differences

\begin{tabular}{|c|c|c|c|c|}
\hline \multicolumn{5}{|c|}{ Dependent variable: $\Delta$ Ln Electricity sales $_{s, y}$} \\
\hline & $(1)$ & (2) & (3) & (4) \\
\hline$\Delta \mathrm{Ln}$ Electricity price $(\mathrm{real})_{s, y}$ & $\begin{array}{l}-0.10^{* * * *} \\
(0.03)\end{array}$ & $\begin{array}{l}-0.09 * * * \\
(0.02)\end{array}$ & $\begin{array}{l}-0.09 * * * \\
(0.02)\end{array}$ & $\begin{array}{l}-0.09 * * * \\
(0.02)\end{array}$ \\
\hline$\Delta$ Ln GDP per capita $(\text { real })_{s, y}$ & & $\begin{array}{l}0.36^{* * * *} \\
(0.04)\end{array}$ & $\begin{array}{l}0.35 * * * \\
(0.04)\end{array}$ & $\begin{array}{l}0.14 * * * \\
(0.05)\end{array}$ \\
\hline$\Delta$ Ln Population $s_{s, y}$ & & $\begin{array}{l}0.83 * * * \\
(0.14)\end{array}$ & $\begin{array}{l}0.80 * * * \\
(0.22)\end{array}$ & $\begin{array}{l}0.68 * * * \\
(0.19)\end{array}$ \\
\hline$\Delta \operatorname{Ln} \mathrm{HDD}_{s, y}$ & & $\begin{array}{l}0.08 * * * \\
(0.02)\end{array}$ & $\begin{array}{l}0.08 * * * \\
(0.02)\end{array}$ & $\begin{array}{l}0.07 * * * \\
(0.02)\end{array}$ \\
\hline$\Delta \operatorname{Ln} \mathrm{CDD}_{s, y}$ & & $\begin{array}{l}0.06^{* * * *} \\
(0.01)\end{array}$ & $\begin{array}{l}0.06^{* * * *} \\
(0.01)\end{array}$ & $\begin{array}{l}0.05 * * * \\
(0.01)\end{array}$ \\
\hline$\Delta$ Ln Natural gas price $(\text { real })_{s, y}$ & & $\begin{array}{l}0.03 * * * \\
(0.00)\end{array}$ & $\begin{array}{l}0.03^{* * *} \\
(0.00)\end{array}$ & $\begin{array}{l}-0.01 \\
(0.01) \\
\end{array}$ \\
\hline State fixed effects & - & - & Yes & Yes \\
\hline Year fixed effects & - & - & - & Yes \\
\hline$R^{2}$ & 0.02 & 0.53 & 0.56 & 0.66 \\
\hline
\end{tabular}

Note: $* * *, * *$, and $*$ indicate statistical significance at 1,5 , and $10 \%$. Estimates use weighted least squares, with a weight equal to the square root of the number of electricity customers in each state*year. Robust standard errors clustered by state are in parentheses. Coefficients on constants and fixed effects not shown. No instrument is used.

\subsection{Short-run estimates}

Table 4 presents our two-dimensional state-year panel estimates in first differences, using data for total electricity sales in each state. Column 1 presents an estimate with no controls. A very inelastic effect is detected: a $1 \%$ increase in electricity prices is typically associated with a sameyear reduction in the quantity of electricity demanded of $0.10 \%$. The point estimate is marginally smaller $(-0.09)$ in the subsequent columns. These columns add the controls and state and year fixed effects.

We find a positive short-run effect of GDP per capita in Table 4, suggesting that electricity demand tends to grow more quickly during years of rapid economic growth (all else equal). The effect of population is strong in the short run, and positive effects of HDD and CDD are obtained. The HDD result implies that colder weather within states leads to more electricity demand. We generally obtain negative coefficients for the year fixed effects (relative to the 2004 base; coefficients not shown), with particularly large negative effects recorded for 2009, 2012, and 2015. Our model is able to explain two-thirds of the year-to-year fluctuations in log electricity sales.

Table 5 presents our three-dimensional estimates. Column 1 has no controls; an elasticity of -0.10 is obtained, similar to the two-dimensional specification. The elasticity remains quite stable once the controls and the state*sector and sector*year fixed effects are added (columns 2-3). Estimates for the control variables are reasonably similar to those in Table 4. Column 4 allows the coefficients for the controls to vary by sector. A same-year price elasticity of demand of -0.10 is again obtained.

Column 5 of Table 5 adds the state*year fixed effects. This results in a more tightly-controlled specification due to a strong cross-correlation between the state*year fixed effects and our differenced log electricity price measure. The same-year price elasticity of electricity demand increases to -0.24 , significantly different from zero at the $10 \%$ level. 


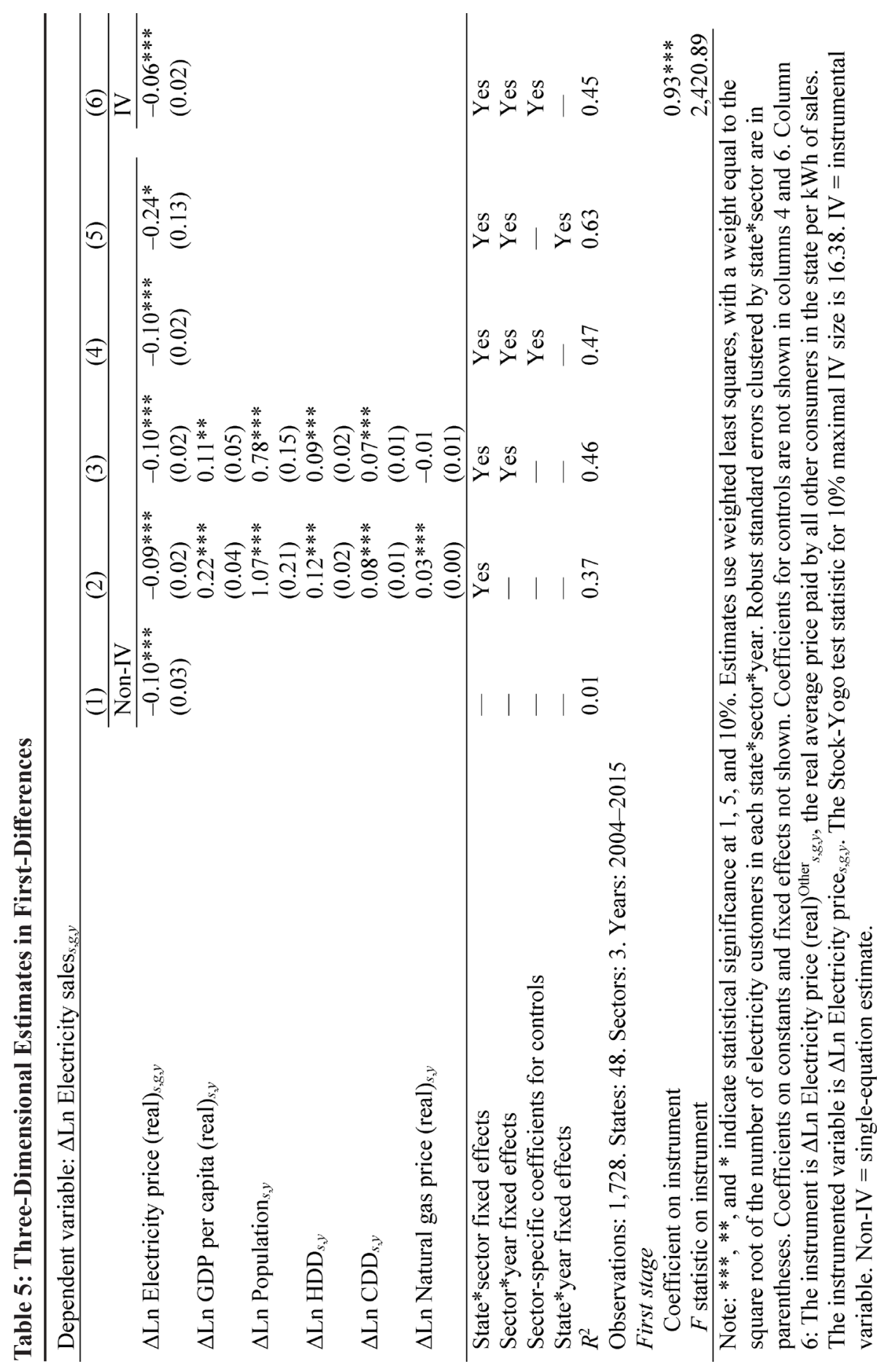


Table 6: Testing for Heterogeneity in Same-Year Elasticity (Three-Dimensional Panel)

\begin{tabular}{|c|c|c|c|c|}
\hline \multicolumn{5}{|l|}{ Dependent variable: $\Delta$ Ln Electricity sales $_{s, g, y}$} \\
\hline & $(1)$ & $(2)$ & (3) & $(4)$ \\
\hline \multicolumn{5}{|l|}{ Sector interactions } \\
\hline$\Delta \mathrm{Ln}$ Electricity price (real) $)_{s, g, y} *$ Residential dummy ${ }_{g}$ & $\begin{array}{l}-0.11^{* * *} \\
(0.02)\end{array}$ & & & \\
\hline$\Delta \mathrm{Ln}$ Electricity price $(\text { real })_{s, g, y} *$ Commercial dummy ${ }_{g}$ & $\begin{array}{l}-0.05 \\
(0.05)\end{array}$ & & & \\
\hline$\Delta \mathrm{Ln}$ Electricity price (real) $)_{s, g,} *$ Industrial dummy ${ }_{g}$ & $\begin{array}{l}-0.11 \\
(0.07)\end{array}$ & & & \\
\hline \multicolumn{5}{|l|}{ Time period interactions } \\
\hline$\Delta$ Ln Electricity price (real) $)_{s, g, y} * 2004-2007$ dummy $_{y}$ & & $\begin{array}{l}-0.07 * * * \\
(0.02)\end{array}$ & & \\
\hline$\Delta \mathrm{Ln}$ Electricity price $(\text { real })_{s, g, y} * 2008-2015$ dummy $_{y}$ & & $\begin{array}{l}-0.11^{* * *} \\
(0.02)\end{array}$ & & \\
\hline \multicolumn{5}{|l|}{ Region interactions } \\
\hline$\Delta$ Ln Electricity price $(\text { real })_{s, g, y} *$ Northeast dummy $_{s}$ & & & $\begin{array}{l}-0.09 * * * \\
(0.03)\end{array}$ & \\
\hline$\Delta \mathrm{Ln}$ Electricity price $(\text { real })_{s, g, y} *$ Midwest dummy ${ }_{s}$ & & & $\begin{array}{l}-0.14 * * * \\
(0.05)\end{array}$ & \\
\hline$\Delta \mathrm{Ln}$ Electricity price $(\text { real })_{s, g, y} *$ South dummy ${ }_{s}$ & & & $\begin{array}{l}-0.08 * * \\
(0.04)\end{array}$ & \\
\hline$\Delta \mathrm{Ln}$ Electricity price $(\text { real })_{s, g, y} *$ West dummy $y_{s}$ & & & $\begin{array}{l}-0.09 * * \\
(0.04)\end{array}$ & \\
\hline \multicolumn{5}{|l|}{ Potential asymmetry interactions } \\
\hline 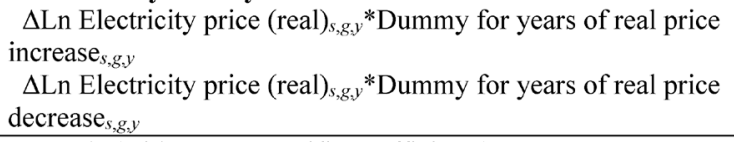 & & & & $\begin{array}{l}-0.11^{* * *} \\
(0.03) \\
-0.07 \\
(0.05)\end{array}$ \\
\hline Controls (with sector-specific coefficients) & Yes & Yes & Yes & Yes \\
\hline State*sector fixed effects & Yes & Yes & Yes & Yes \\
\hline Sector*year fixed effects & Yes & Yes & Yes & Yes \\
\hline$R^{2}$ & 0.47 & 0.48 & 0.47 & 0.47 \\
\hline \multicolumn{5}{|l|}{ Observations: 1,728. States: 48. Sectors: 3. Years: 2004-2015 } \\
\hline $\begin{array}{l}\text { Note: } * * *, * * \text { and } * \text { indicate statistical significance at } 1,5 \text {, and } \\
\text { weight equal to the square root of the number of electricity cust } \\
\text { errors clustered by state* sector are in parentheses. Coefficients } \\
\text { No instrument is used. }\end{array}$ & . Estimat & use weigh & $\begin{array}{l}\text { least squ } \\
\text { ar. Robus } \\
\text { ed effects }\end{array}$ & $\begin{array}{l}\text { with a } \\
\text { ndard } \\
\text { shown. }\end{array}$ \\
\hline
\end{tabular}

Column 6 of Table 5 instruments each sector's log change in average electricity price with the log change in the average price of electricity paid by all consumers outside the sector but in the same state and year. The instrument is not directly affected by changes in the level of electricity demand within each individual sector. We allow sector-specific coefficients for the controls. The instrument performs well in the first stage, obtaining a large $F$-statistic. We obtain a smaller shortrun price elasticity of electricity demand of -0.06 . This estimate is significantly different from zero at the $1 \%$ level. As our headline result we report a short-run price elasticity of electricity demand of around -0.1 , the mean of our estimates in Tables 4 and 5 .

Table 6 presents heterogeneity analysis for the short-run price elasticity of electricity demand. We utilize the three-dimensional dataset so as to exploit possible heterogeneity in effects along each of the dimensions. We include the controls and fixed effects, with the exception of the state*year fixed effects so as to avoid the issue of over-controlling. We allow the coefficients for the controls to vary by sector.

Column 1 of Table 6 explores for sectoral differences in the same-year price elasticity of electricity demand. We find larger point estimates for industry and residences $(-0.11$ for each), although the elasticity for industry is not significantly different from zero. For the commercial sector, 
we find a statistically insignificant elasticity of -0.05 . The same-year elasticities for the three sectors are not significantly different from one another. ${ }^{19}$

Column 2 of Table 6 tests if the same-year price elasticity of electricity demand for 20082015 (after the onset of the Great Recession) has differed from the elasticity for earlier years. Our motivation for exploring this issue is that the trajectory of U.S. electricity use has changed substantially, and it is possible that the price elasticity of electricity demand has too. The results suggest that the same-year elasticity has increased slightly, from -0.07 to -0.11 , with the difference significantly different from zero at the $1 \%$ level.

Column 3 of Table 6 estimates separate same-year price elasticities of electricity demand for four regions of the United States. ${ }^{20}$ In point estimate terms, the largest elasticity is for the Midwest and the smallest for the South. These elasticities do not significantly differ from one another. We therefore conclude that there is not strong evidence of substantial regional heterogeneity in the short-run price elasticity of electricity demand in the U.S.

It is possible that the short-run price elasticity of electricity demand differs in years of real price increases and years of real price decreases. To test this, column 4 of Table 6 includes separate differenced log price terms for years of increase (59\% of observations) and years of decrease (41\%) in the average real electricity price of each state*sector. A larger coefficient is obtained for years of real price increases, although one that is not significantly different from the coefficient for years of real price decreases.

\section{CONCLUSION}

In this study we used three-dimensional data to estimate aggregate short- and long-run price elasticities of electricity demand in the U.S. In the long run, electricity demand by industry is the most price responsive, with an elasticity of -1.2 or larger. The long-run price elasticity of electricity demand for the commercial sector is -0.3 to -0.6 , and for residences around -1 . Total state demand for electricity has a long-run price elasticity of around -1 , similar to the residential group. The same-year price elasticity of electricity demand is on average around -0.1 . Much of the demand response to electricity prices is thus delayed.

A largely delayed response to electricity price changes makes sense. Many activities are difficult to adjust in the short run, as the capital stock has already been acquired and put to use. In the long run, factors are able to adjust more flexibly. Energy efficiency improvements to the building stock, for example, can pan out over decades. Electricity-intensive activities can also locate in states with low electricity prices.

Our study does not examine specific substitution responses to electricity price changes. For example we do not estimate the extent to which electricity price increases encourage the use of energy-efficient technologies, induce substitution to off-grid electricity sources, or induce relocation. Future research might examine such responses.

Dramatic ongoing reductions in the costs of generating electricity using solar panels and wind turbines suggest that a future of low electricity prices may one day be possible (Bloomberg New Energy Finance, 2016). Our estimates suggest that the immediate demand-side effects of any

19. The three-dimensional estimate in column 1 of Table 6 provides identical coefficients to separate two-dimensional (state, year) estimates by sector. This is because all coefficients (including the constant) have been given freedom to vary by sector. The standard errors for the electricity price term are slightly lower in the three-dimensional setting.

20. Regional definitions are in the Appendix. 
future reductions in electricity prices are likely to be small. If current differentials across states serve as a guide, the long-run demand-side effects of lower electricity prices may be considerably larger.

\section{ACKNOWLEDGMENTS}

We are grateful for comments from Zsuzsanna Csereklyei, anonymous referees, and attendees at a presentation at the Indonesian Institute of Sciences (LIPI). Funding was received from the Australian Research Council (DE160100750).

\section{REFERENCES}

Alberini, A. and M. Filippini (2011). "Response of Residential Electricity Demand to Price: The Effect of Measurement Error.” Energy Economics 33(5): 889-895. https://doi.org/10.1016/j.eneco.2011.03.009.

American Public Power Association (2016). Retail Electric Rates in Deregulated and Regulated States: 2015 Update. Arlington, VA: American Public Power Association.

Baltagi, B.H. (2008). Econometric Analysis of Panel Data. 4th ed. West Sussex, UK: John Wiley \& Sons.

Baltagi, B.H. and J.M. Griffin (1984). "Short and Long Run Effects in Pooled Models.” International Economic Review 25(3): 631-645. https://doi.org/10.2307/2526223.

Barro, R.J. (2015). “Convergence and Modernisation.” Economic Journal 125(585): 911-942. https://doi.org/10.1111/ ecoj. 12247.

Bazzi, S. and M.A. Clemens. (2013). "Blunt Instruments: Avoiding Common Pitfalls in Identifying the Causes of Economic Growth.” American Economic Journal: Macroeconomics 5(2): 152-86. https://doi.org/10.1257/mac.5.2.152.

Bloomberg New Energy Finance (2016). New Energy Outlook 2016.

Blundell, R. and S. Bond (1998). "Initial Conditions and Moment Restrictions in Dynamic Panel Data Models." Journal of Econometrics 87(1): 115-143. https://doi.org/10.1016/S0304-4076(98)00009-8.

Borenstein, S. and J. Bushnell (2015). "The U.S. Electricity Industry After 20 Years of Restructuring." Annual Review of Economics 7: 437-463. https://doi.org/10.1146/annurev-economics-080614-115630.

Breusch, T. S. and A.R. Pagan (1979). "A Simple Test for Heteroscedasticity and Random Coefficient Variation.” Econometrica 47: 1287-1294. https://doi.org/10.2307/1911963.

Bun, M.J.G. and F. Windmeijer (2010). "The Weak Instrument Problem of the System GMM Estimator in Dynamic Panel Data Models.” Econometrics Journal 13(1): 95-126. https://doi.org/10.1111/j.1368-423X.2009.00299.x.

Bureau of Economic Analysis. (2017). U.S. Economic Accounts, http://www.bea.gov/index.htm.

Bureau of Labor Statistics. (2017). Consumer Price Index. https://www.bls.gov/cpi/.

Burke, P.J. and S. Nishitateno (2013). "Gasoline Prices, Gasoline Consumption, and New-Vehicle Fuel Economy: Evidence for a Large Sample of Countries.” Energy Economics 36: 363-370. https://doi.org/10.1016/j.eneco.2012.09.008.

Burke, P.J. and S. Nishitateno (2015). “Gasoline Prices and Road Fatalities: International Evidence.” Economic Inquiry 53(3): 1437-1450. https://doi.org/10.1111/ecin.12171.

Burke, P.J. and H. Yang (2016). “The Price and Income Elasticities of Natural Gas Demand: International Evidence.” Energy Economics 59: 466-474. https://doi.org/10.1016/j.eneco.2016.08.025.

Delgado, M.S., D.J. Henderson and C.F. Parmeter (2014). "Does Education Matter for Economic Growth?" Oxford Bulletin of Economics and Statistics 76(3), 334-359. https://doi.org/10.1111/obes.12025.

Dergiades, T. and L. Tsoulfidis (2008). "Estimating Residential Demand for Electricity in the United States, 1965-2006." Energy Economics 30(5): 2722-2730. https://doi.org/10.1016/j.eneco.2008.05.005.

Dickey, D.A. and W.A. Fuller (1979). "Distribution of the Estimators for Autoregressive Time Series with a Unit Root." Journal of the American Statistical Association 74(366): 427-431. https://doi.org/10.2307/2286348.

Dietz, T., K.A. Frank, C.T. Whitley, J. Kelly and R. Kelly (2015). "Political Influences on Greenhouse Gas Emissions from US States." Proceedings of the National Academy of Sciences 112(27): 8254-8259. https://doi.org/10.1073/pnas.1417806112.

Edwards, R.B. (2016). "Mining Away the Preston Curve." World Development 78, 22-36. https://doi.org/10.1016/j. worlddev.2015.10.013.

Ellison, G. and E.L. Glaeser (1999). "The Geographic Concentration of Industry: Does Natural Advantage Explain Agglomeration?" American Economic Review: Papers and Proceedings 89(2): 311-316. https://doi.org/10.1257/aer.89.2.311.

Fell, H., S. Li and A. Paul (2014). "A New Look at Residential Electricity Demand Using Household Expenditure Data." International Journal of Industrial Organization 33: 37-47. https://doi.org/10.1016/j.ijindorg.2014.02.001.

All rights reserved. Copyright $(C) 2018$ by the IAEE. 
Hauk, W.R. (2017). "Endogeneity Bias and Growth Regressions.” Journal of Macroeconomics 51: 143-161. https://doi. org/10.1016/j.jmacro.2017.01.001.

Hauk, W.R. and R. Wacziarg (2009). "A Monte Carlo Study of Growth Regressions.” Journal of Economic Growth 14(2): 103-147. https://doi.org/10.1007/s10887-009-9040-3.

Havranek, T., Z. Irsova and K. Janda (2012). "Demand for Gasoline is More Price-Inelastic than Commonly Thought." Energy Economics 34: 201-207. https://doi.org/10.1016/j.eneco.2011.09.003.

Houthakker, H.S. (1980.) "Residential Electricity Revisited." The Energy Journal 1(1): 29-41. https://doi.org/10.5547/ ISSN0195-6574-EJ-Vol1-No1-4.

Ito, K. (2014). "Do Consumers Respond to Marginal or Average Price? Evidence from Nonlinear Electricity Pricing." American Economic Review 104(2): 537-563. https://doi.org/10.1257/aer.104.2.537.

Jessoe, K. and D. Rapson (2014) 'Knowledge is (Less) Power: Experimental Evidence from Residential Energy Use.” American Economic Review 104(4): 1417-1438. https://doi.org/10.1257/aer.104.4.1417.

Kahn, M.E. and E.T. Mansur (2013). "Do Local Energy Prices and Regulation Affect the Geographic Concentration of Employment?" Journal of Public Economics 101: 105-114. https://doi.org/10.1016/j.jpubeco.2013.03.002.

Labandeira, X., J.M. Labeaga and X. López-Otero (2017). "A Meta-Analysis on the Price Elasticity of Energy Demand." Energy Policy 102: 549-568. https://doi.org/10.1016/j.enpol.2017.01.002.

Ma, C. and D.I. Stern (2016). "Long-Run Estimates of Interfuel and Interfactor Elasticities." Resource and Energy Economics 46, 114-130. https://doi.org/10.1016/j.reseneeco.2016.09.003.

Miller, M. and A. Alberini (2016). "Sensitivity of Price Elasticity of Demand to Aggregation, Unobserved Heterogeneity, Price Trends, and Price Endogeneity: Evidence from U.S. Data.” Energy Policy 97: 235-249. https://doi.org/10.1016/j. enpol.2016.07.031.

National Oceanic and Atmospheric Administration (NOAA) (2016). Climate at a Glance. http://www.ncdc.noaa.gov/cag/ time-series/us/11/0/cdd/ytd/12/1990-2016.

Nickell, S. (1981). "Biases in Dynamic Models with Fixed Effects." Econometrica 49(6): 1417-1426. https://doi. org/10.2307/1911408.

Pesaran, M.H. and R. Smith (1995). "Estimating Long-Run Relationships from Dynamic Heterogeneous Panels.” Journal of Econometrics 68(1): 79-113. https://doi.org/10.1016/0304-4076(94)01644-F.

Pirotte, A. (1999). "Convergence of the Static Estimation Toward the Long Run Effects of Dynamic Panel Data Models." Economics Letters 63(2): 151-158. https://doi.org/10.1016/S0165-1765(99)00023-3.

Pirotte, A. (2003). "Convergence of the Static Estimation Toward the Long Run Effects of Dynamic Panel Data Models: A Labour Demand Illustration.” Applied Economics Letters 10(13): 843-847. https://doi.org/10.1080/1350485032000137486.

Roodman, D. (2009). "How to do xtabond2: An Introduction to Difference and System GMM in Stata." Stata Journal 9(1): 86-136.

Ros, A.J. (2017). “An Econometric Assessment of Electricity Demand in the United States Using Utility-Specific Panel Data and the Impact of Retail Competition on Prices.” The Energy Journal 38(4): 73-99. https://doi.org/10.5547/01956574.38.4.aros.

Shin, J.S. (1985). "Perception of Price when Price Information is Costly: Evidence from Residential Electricity Demand." Review of Economics and Statistics 67(4): 591-598. https://doi.org/10.2307/1924803.

Stern, D.I. (2010). "Between Estimates of the Emissions-Income Elasticity.” Ecological Economics 69(11): $2173-2182$. https://doi.org/10.1016/j.ecolecon.2010.06.024.

Stock, J.H. and M. Yogo (2005). "Testing for Weak Instruments in Linear IV Regression.” In Identification and Inference for Econometric Models: Essays in Honor of Thomas Rothenberg, eds. Andrews, D.W.K. and Stock, J.H, 80-108. Cambridge, UK: Cambridge University Press. https://doi.org/10.1017/CBO9780511614491.006.

Sun, Y. and Y. Yu (2017). "Revisiting the Residential Electricity Demand in the United States: A Dynamic Partial Adjustment Modelling Approach.” Social Science Journal, 54(3): 295-304. https://doi.org/10.1016/j.soscij.2017.02.004.

United States Census Bureau (2011). Statistical Abstract of the United States: 2012, http://www.census.gov/library/ publications/2011/compendia/statab/131ed.html.

United States Census Bureau (2016). Regions and Divisions, https://www.census.gov/geo/reference/gtc/gtc_census_divreg. html.

U.S. Energy Information Administration (2014). Price Elasticities for Energy Use in Buildings of the United States. Washington, DC: U.S. Energy Information Administration.

U.S. Energy Information Administration (2016a). Electricity: Detailed State Data, https://www.eia.gov/electricity/data/state/.

U.S. Energy Information Administration (2016b). U.S. Energy Facts Explained, http://www.eia.gov/ energyexplained/?page=us_energy_home.

U.S. Energy Information Administration (2016c). Electricity Explained: Factors Affecting Electricity Prices, http://www.eia. gov/energyexplained/index.cfm?page=electricity_factors_affecting_prices.

Copyright (C) 2018 by the IAEE. All rights reserved. 
U.S. Energy Information Administration (2016d). Electric Power Annual, http://www.eia.gov/electricity/annual/.

U.S. Energy Information Administration (2016e). Natural Gas, https://www.eia.gov/dnav/ng/ng_pri_sum_dcu_nus_m.htm.

U.S. Energy Information Administration (2016f). Electric Power Monthly, http://www.eia.gov/electricity/monthly/.

U.S. Energy Information Administration (2017). Annual Energy Outlook 2017 with Projections to 2050. Washington, DC:

U.S. Energy Information Administration.

U.S. Geological Survey (2016). 2015 Minerals Yearbook: Aluminum. https://minerals.usgs.gov/minerals/pubs/commodity/ aluminum/.

Wooldridge, J. M. (2002). Econometric Analysis of Cross Section and Panel Data. Cambridge, MA: MIT Press.

\section{APPENDIX: VARIABLE DESCRIPTIONS}

Electricity sales: Quantity of sales of electricity to ultimate customers, in gigawatt-hours. Data are for a census of electricity providers. The variable does not cover direct use of electricity generated by an entity or affiliate. Source: U.S. EIA (2016a).

Electricity price (real): Average end-user electricity price, in year-2015 cents/kWh. Data are for a census of electricity providers, and are calculated by dividing revenues by quantities. Includes taxes (state and local), energy charges (e.g. for transmission/distribution), demand charges, customer service charges, environmental surcharges, franchise fees, fuel adjustments, and other miscellaneous charges to end-use customers. Does not include deferred charges, credits, or adjustments, e.g. revenue from electricity purchased in prior reporting periods (U.S. Census Bureau, 2011). Source: U.S. EIA (2016a). We constructed a real measure by deflating with the regional consumer price index from the Bureau of Labor Statistics (2017).

Electricity customers: Number of electricity customers. Data are for a census of electricity providers. Source: U.S. EIA (2016a).

The above three variables vary by state, sector, and year. Consistent sector definitions are available for 2003 onwards. The sectors are:

- Residential: Customers in single and multi-family residences, apartments, and mobile homes. Excludes institutional living quarters (e.g. prisons).

- Commercial: Retail, office, education, institutional, and public-sector customers, plus outdoor and public street lighting. Includes institutional living quarters (e.g. prisons); private and public organizations such as religious, social, or fraternal groups; interdepartmental sales; other sales to public authorities.

- Industrial: Facilities and equipment used for producing, processing, or assembling goods. Includes manufacturing; agriculture, forestry, fishing and hunting; mining and oil and gas extraction; construction.

- Total: Residential + commercial + industrial + transportation.

The U.S. EIA (2016f) notes that "changes from year to year in consumer counts, sales and revenues, particularly involving the commercial and industrial consumer sectors, may result from respondent implementation of changes in the definitions of consumers, and reclassifications".

Gross domestic product per capita (real): Real GDP in chained 2009 dollars divided by mid-year population estimate. Measured at the state*year level. Data follow the North American Industry Classification System (NAICS). Source: BEA (2017).

Population: Mid-year population estimate, in number of persons. Measured at the state*year level. Source: BEA (2017).

Heating degree days: Number of degrees each day's average temperature is below $65^{\circ}$ Fahrenheit, summed by day to an annual aggregate. The data are the average estimated number of 
heating degree days, population-weighted across climate divisions in each state. Unit: Fahrenheit degree days. Measured at the state*year level. Source: NOAA (2016).

Cooling degree days: Number of degrees each day's average temperature is above $65^{\circ}$ Fahrenheit, summed by day to an annual aggregate. The data are the average estimated number of cooling degree days, population-weighted across climate divisions in each state. Unit: Fahrenheit degree days. Measured at the state*year level. Source: NOAA (2016).

Natural gas price: Natural gas citygate price, in year-2015 dollars per thousand cubic feet. The citygate is where a distributing utility receives gas from a natural gas company or transmission system. Measured at the state*year level. Source: U.S. EIA (2016e). We constructed a real measure by deflating by the regional consumer price index from the Bureau of Labor Statistics (2017).

Environmental voting score (1990-2005): League of Conservation Voters score for pro-environmental voting by each state's Senate and House delegations for the period 1990-2005. The League provides a score for each member of Congress in each year, on a scale of 0 (lowest) to 100 (highest). The League also provides an average for the Senate and House delegations of each state in each year. We use the average of each state's Senate and House scores in each year, as provided by Dietz et al. (2015). We then take the time-invariant average for 1990-2005.

Coal + hydroelectricity share of electricity mix: Coal-fired + conventional hydroelectricity share of net generation. Ranges between 0 and 1. Calculated using data in megawatt hours. Measured at the state*year level. Source: U.S. EIA (2016a).

Regions:

- Northeast: Connecticut, Maine, Massachusetts, New Hampshire, New Jersey, New York, Pennsylvania, Rhode Island, Vermont.

- Midwest: Illinois, Indiana, Iowa, Kansas, Michigan, Minnesota, Missouri, Nebraska, North Dakota, Ohio, South Dakota, Wisconsin.

- South: Alabama, Arkansas, Delaware, Florida, Georgia, Kentucky, Louisiana, Maryland, Mississippi, North Carolina, Oklahoma, South Carolina, Tennessee, Texas, Virginia, West Virginia.

- West: Arizona, California, Colorado, Idaho, Montana, Nevada, New Mexico, Oregon, Utah, Washington, Wyoming.

- Source: U.S. Census Bureau (2016).

Years: Calendar years.

States: Our state-based regression analysis excludes Alaska, Hawaii, and Washington DC due to missing data on cooling and heating degree days, natural gas price, and/or environmental voting score. National data include Alaska, Hawaii, and Washington DC. 


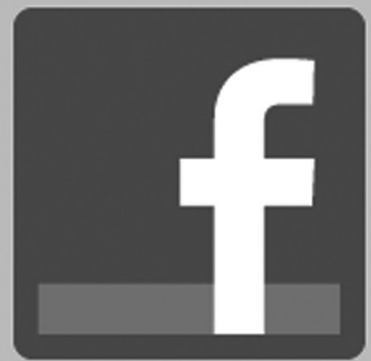

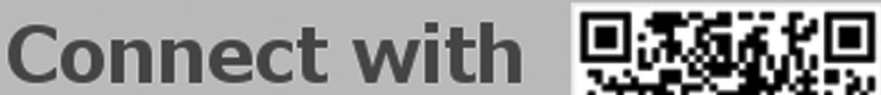

